\title{
Preliminary Assessment of Growth Rates on Different Concentration of Microalgae Scenedesmus sp. in Industrial Meat Food Processing Wastewater
}

\author{
Nur Atikah Ahmad Latiffi ${ }^{1}$, Radin Maya Saphira Radin Mohamed ${ }^{1, *}$, Najeeha Mohd \\ Apandi ${ }^{1}$, and Ramlah Mohd Tajuddin ${ }^{2}$ \\ ${ }^{1}$ Faculty of Civil and Environmental Engineering, Universiti Tun Hussein Onn Malaysia, Johor, \\ Malaysia \\ ${ }^{2}$ Faculty of Civil Engineering, University Technology MARA, UiTM, Selangor, Malaysia
}

\begin{abstract}
This study is aimed to evaluate and access the growth rates and biomass productivity in different concentrations of microalgae Scenedesmus sp. using Industrial Meat Food Processing Wastewater as a media. The focus of this study is to determine the best concentrations of microalgae Scenedesmus sp. in raw wastewater in terms of kinetics of cells growth rates. The study verified that concentration of $1 \times 10^{6}$ cells $/ \mathrm{ml}$ of microalgae gives the highest specific growth rates of biomass at 0.4488 day-1 and $1720 \mathrm{cells} / \mathrm{ml} /$ day compare to the other concentrations, while the lowest occurred at concentration of $1 \times 10^{3}$ cells $/ \mathrm{ml}$ at 0.4108 day $^{-1}$ and 14.9 cells $/ \mathrm{ml} /$ day. The result shows the different concentration of microalgae Scenedesmus sp. culturing in Industrial Food Processing Wastewater influence the cells growth of biomass and the optimum were obtained at concentration of $1 \times 10^{6}$ cells $/ \mathrm{ml}$ which suggested use for Industrial Meat Food Processing Wastewater Treatment purposed. With this finding, it should be seemly to adopt and applied efficiently in treating the wastewater especially for Scenedesmus $s p$. type of microalgae.
\end{abstract}

\section{Introduction}

Microalgae are known as a survival microorganism which can grow and adapt well in an extreme environmental conditions such as in various type of wastewater. However, there are some species who can only survive in certain type of conditions [1]. There are more 50,000 species of microalgae has been found which varies from types, species, size and organism groups [2-4]. The structure of algae typically comprises of plastids chlorophyll which ensuing photosynthesis process that devours light as energy and converts inorganic substance into sugar [5-6]. This expressions indicates that microalgae has absorption ability indirectly can restore and reduce substances from wastewater [7].

* Corresponding author: maya@uthm.edu.my 
Wastewater normally contains high amount of organic matter as well as inorganic nutrients and according to [8] cultivation of microalgae for biomass productions by using wastewater can significantly reduce the water usage up to $90 \%$. This can be achieved by assimilating all the nutrients present in wastewater. Industrial Meat Food Processing wastewater is known to be highly biodegradable, non-toxic and rich in nitrogen and phosphorus elements. Its characteristics is differ comparing with typical municipal wastewater that managed by public treatment plants as it is difficult to predict due to the seasonal and demand nature of business [9]. Activities involving in the meat processing industries known to be high in water usage up to $62 \mathrm{Mm}^{3} /$ year, as only a small amount from this total are fully utilized into the final products, subsequently the rest of wastewater been discharge into the water bodies [10] and according to [11], meat food processing facility itself are using clean water up to $40 \mathrm{~m}^{3} /$ metric tons of meat products which is the highest consumers compare with other food and beverage industries by $24 \%$ [11-12]. All the steps involved in the process of production until packaging indirectly gives an impact to the environmental as the waste generates from all of these process will eventually initiate several environmental problems to human beings and aquatic organism as they both rely on water to sustained $[9,12]$. Furthermore, nitrogen and phosphorus are an ideal and essentials nutrients that can stimulate a fast growth of algae in freshwater, wastewater streams from varies of sources such as from agricultural run-off, industrial, municipal wastewater and marine ecosystem [13-14]. Even though wastewater could possibly offer some essentials goods for microalgae cultivation activity, however, the raw wastewater compositions are differ compare to the culture medium prepared in the laboratory. Concentration of nitrogen and phosphorus as well as the existent wide range of other microorganism, presence of heavy metals and other toxics comes from wastewater may interfere the growth and uptake of nutrients by microalgae [15]. On the other hand, nitrogen presents in wastewater normally in ammonia forms which can restrain microalgae growth if high in concentration $[1,16,17]$. Therefore, the most significant key in selecting the best concentration of microalgae is it can strongly adapt and have high specific growth rates interpretation in selected wastewater.

\section{Materials and methods}

\subsection{Microalgae Scenedesmus sp.}

Three (3) steps of procedure on preparations of microalgae i.e. microalgae sampling, isolation and identification need to be done prior culturing. Microalgae of Scenedesmus sp. was obtained from plankton located in Endau Rompin National Park, Johor. This location is selected due to well preserved national park that has less environmental pollution which contributes to a better colonies and growth. Many previous studies by [18-19] have been used and applied microalgae from this location for treatments and growth studies that portrayed effective results and outcome. A sterilize glass bottle was used for collection and seal with cotton wool for preservations to allowed air flow and photosynthesis. A small amount of algae were isolated and isolation process was done under microscope by using platinum needles. The isolated microalgae then will be examined for initial identification and confirmation using NIKON Eclipse E600 microscope. For culturing, the isolated microalgae is cultivate in Basal Bold Medium, BBM [20] and later were place under natural condition of $12 \mathrm{~h}$ : $12 \mathrm{~h}$ intensity lights with temperature $\pm 35^{\circ} \mathrm{C}$ for growth observations. 


\subsection{Wastewater Sampling Preparations}

Sample was collected at one of small and medium food industries located in Johor. Sampling was done once a week for 8 weeks duration to get the average values and range. The collected wastewater was preserve in plastic bottle of Polyethylene Terephthalate (PET) and was stored at $4^{0} \mathrm{C}$ without any acid preservation. Wastewater that was collected from the study site were filtered before inoculation process takes place to minimized all unwanted microorganism or bacteria that may exists in the wastewater.

\subsection{Inoculations of different microalgae Scenedesmus sp. concentration for laboratory batch optimizations}

Six (6) different concentration of microalgae Scenedesmus sp. was prepared and use in this batch study i.e. concentration $1 \times 10^{3}$ cells $/ \mathrm{ml}, 1 \times 10^{4}$ cells $/ \mathrm{ml}, 1 \times 10^{5}$ cells $/ \mathrm{ml}, 1 \times 10^{6}$ cells $/ \mathrm{ml}$, and $1 \times 10^{7}$ cells $/ \mathrm{ml}$ respectively. The concentration was calculated using haemocytometer together with equations by Stephenson [21] i.e. $\mathrm{C}_{1} \mathrm{~V}_{1}=\mathrm{C}_{2} \mathrm{~V}_{2}$ where by $\mathrm{C}_{1}$ is the initial concentration of the stocks solutions, $\mathrm{V}_{1}$ is the amount of stock solution required, $\mathrm{C}_{2}$ is the concentration of the wanted stock concentration and $\mathrm{V}_{2}$ is the volume of the stock solutions. This equation is suitable for solution, mixture and media as stated by Stephenson [21]. The growth rates data were collected and counted for every 24 hours until the growth enter the death or decline stage [22].

\section{Cells Concentration Counting}

Microalgae cell concentration was determined through cell counting using haemocytometer [23-24]. The haemocytometer is a slide glass size $30 \mathrm{~mm} \times 70 \mathrm{~mm} \times 4 \mathrm{~mm}$ thick. It has 3 chambers and cells counts are performed at the center part. The specific growth rates of microalgae were calculated using Eq. 1 derives formula from Andersen R.A. [24] i.e. $\mu$ / day $=\left(\operatorname{Ln}\left(\mathrm{N}_{\mathrm{t}} / \mathrm{N}_{\mathrm{o}}\right) /\left(\mathrm{t}_{\mathrm{f}}-\mathrm{t}_{\mathrm{i}}\right)\right)$. Where $\mathrm{N}_{\mathrm{t}}$ is Final algae concentrations, $\mathrm{N}_{0}$ is Initial algae concentrations and $\Delta_{\mathrm{t}}$ are subtraction of Final time with the Initial time (day).

\section{Data Analysis}

\subsection{Microalgae Scenedesmus sp. characteristics}

Characteristics of microalgae Scenedesmus sp. is shown in Table 1 and its physical characteristics is shown in Fig. 1 by using SEM micrograph. 
Table 1. Characteristics of microalgae Scenedesmus sp.

\begin{tabular}{|c|c|}
\hline Parameters & Values \\
\hline $\mathrm{pH}$ & 6.38 \\
\hline Total Suspended Solid, TSS $(\mathrm{mg} / \mathrm{L})$ & 375 \\
\hline Turbidity $(\mathrm{NTU})$ & 77.8 \\
\hline${\text { Sulfate, } \mathrm{SO}_{4}{ }^{2-}(\mathrm{mg} / \mathrm{L})}$ & 35 \\
\hline Dissolved Oxygen, DO $(\mathrm{mg} / \mathrm{L})$ & 16.38 \\
\hline Total Nitrogen, TN $(\mathrm{mg} / \mathrm{L})$ & 308.9 \\
\hline Total Phosphorus, TP $(\mathrm{mg} / \mathrm{L})$ & 0.75 \\
\hline Total Organic Carbon, TOC $(\mathrm{mg} / \mathrm{L})$ & 38.01 \\
\hline Ammonia Nitrogen, $\mathrm{NH}_{3}-\mathrm{N}(\mathrm{mg} / \mathrm{L})$ & 1.95 \\
\hline Zinc, $\mathrm{Zn}(\mathrm{mg} / \mathrm{L})$ & 0.47 \\
\hline Copper, $\mathrm{Cu}(\mathrm{mg} / \mathrm{L})$ & 1.24 \\
\hline
\end{tabular}

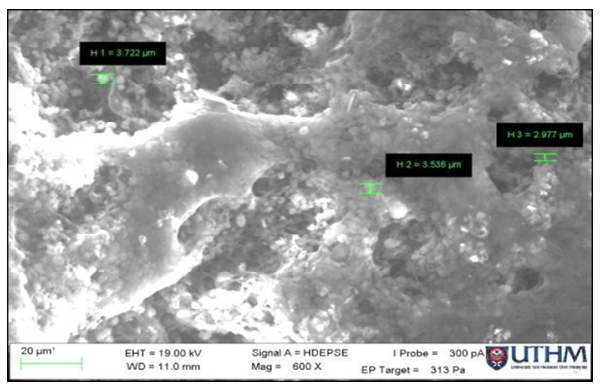

Fig. 1. SEM micrgraph (600X) of Scenedesmus sp.

\subsection{Industrial Meat Food Processing Wastewater Characteristics}

Wastewater characterization is significantly important as it is to determine the availability of nutrients in the wastewater for microalgae growth. Table 2 shows the physical and chemical parameter of meat processing wastewater in comparison with standard discharge effluent allowable by local authorities. Chemical Oxygen Demand (COD) generally defined as the total quantity of oxygen required for complete oxidation of organic compound to carbon dioxide and water and it is significantly to continually measure to determine the degree of pollution in an effluents [25]. Concentration of COD is $1643 \mathrm{mg} / \mathrm{L}$, which is over the allowable limit permit by the local authorities. $\mathrm{BOD}_{5}$ is known to be the basic of parameter in finding the degree of pollutions in water. As for Biological oxygen demand, (BOD), the concentration of the wastewater is $895 \mathrm{mg} / \mathrm{L}$ which also above the limits of standard A and Standard B. This wastewater also contains other parameter such as Total Nitrogen, Ammonia Nitrogen, Total Phosphorus, Orthophosphate, Total Organic Carbon, Total Suspended Solids as well as Total Dissolved Solids with concentration of $151 \mathrm{mg} / \mathrm{L}$, $10 \mathrm{mg} / \mathrm{L}, 45 \mathrm{mg} / \mathrm{L}, 35 \mathrm{mg} / \mathrm{L}, 333 \mathrm{mg} / \mathrm{L}, 333 \mathrm{mg} / \mathrm{L}$ and $1120 \mathrm{mg} / \mathrm{L}$ respectively. All of the mentions parameters are way above limits line as indicate in the [26]. In terms of $\mathrm{pH}$, the wastewater $\mathrm{pH}$ value is acceptable and fit for microalgae cultivation as refer to [27]. There have been few researchers who have done and shown some potentials in cultivating microalgae in other different types of raw wastewater [28-31], or phycoremediation and bio transform those pollutants to essentials biomass as well as cleaned the wastewater at the same time. Moreover, growth efficiency of the cells is subjected to several of environmental factors and nutrients availability. Therefore, this study is to utilized raw 
industrial meat food processing wastewater into cultivating the scenedesmus $s p$. for the growth cells efficiency.

\subsection{Cell Growth of Scenedesmus sp. in Industrial Meat Food Processing Wastewater}

The growth of Scenedesmus sp. cells curve in the industrial meat food processing wastewater are showing positive growing over time for all concentration except for $1 \times 10^{7}$ cells/ml. A typical growth of curve for microorganism as stated by Shuler [22] consist of five (5) phase; the lag, exponential, deceleration, stationary and death or decline phase. As for these experimental growth (Fig. 2), cells of $1 \times 10^{3}$ cells $/ \mathrm{ml}, 1 \times 10^{4}$ cells $/ \mathrm{ml}, 1 \times 10^{5}$ cells $/ \mathrm{ml}$ and $1 \times 10^{6}$ cells $/ \mathrm{ml}$ shows an increasing of biomass concentration over time except for $1 \times 10^{7}$ cells $/ \mathrm{ml}$. The results of growth are similar to the growth of Botryococcus sp.in domestic wastewater that has been reported by Gani [28], whereby, too much of populations of microalgae will cause suffocation of nutrients available in the wastewater to sustained the microalgae growth, resulting no increasing of biomass concentrations over time and based [22], at high concentration of microalgae in the medium, the growth rates will inhibited.

Table 2. Characteristics of the Industrial Meat Food Processing Wastewater used as growth media for Scenedesmus sp. Sampling date: January $2015 \sim$ February 2015.

\begin{tabular}{cccc}
\hline Physiochemical parameters & $\begin{array}{c}\text { Average } \\
\text { Concentrations } \\
\text { Mg/L }\end{array}$ & *Standard A & *Standard B \\
\hline Biological Oxygen Demand, BOD & $1070 \pm 350.913$ & 20 & 50 \\
Chemical Oxygen Demand, COD & $2350 \pm 835.427$ & 50 & 100 \\
Total Nitrogen & $317.22 \pm 171.147$ & - & - \\
Total Phosphorus & $62.86 \pm 36.525$ & 5 & 10 \\
Orthophosphate & $47.37 \pm 27.530$ & - & - \\
Total Organic Carbon & $493.82 \pm 267.881$ & - & - \\
Total Suspended Solids, TSS & $1400 \pm 299.100$ & 50 & 100 \\
\hline$\quad$ pH & $6.5-8.0$ & $6.0-9.0$ & $5.5-9.0$ \\
\hline *EQA, 1974 & & &
\end{tabular}

Fig. 2 shows the comparison between the collected experimental data in comparing with mathematical modeling [32]. Each of specific growth rates of the concentrations can be calculated and obtained during the exponential phase of the microalgae growth by drawing a straight line that touched at least three or more points in Fig. 3 as accordingly to Andersen [24] methods. The growing curve between experimental data and modeling data is considerably different as during experiments works, lots of other factors such as environmental factors, equipment's error and human errors contribute during the analysis.

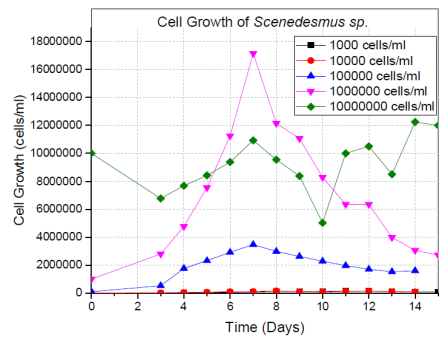

Fig. 2. Scenedesmus sp. growth curve in different concentrations. 

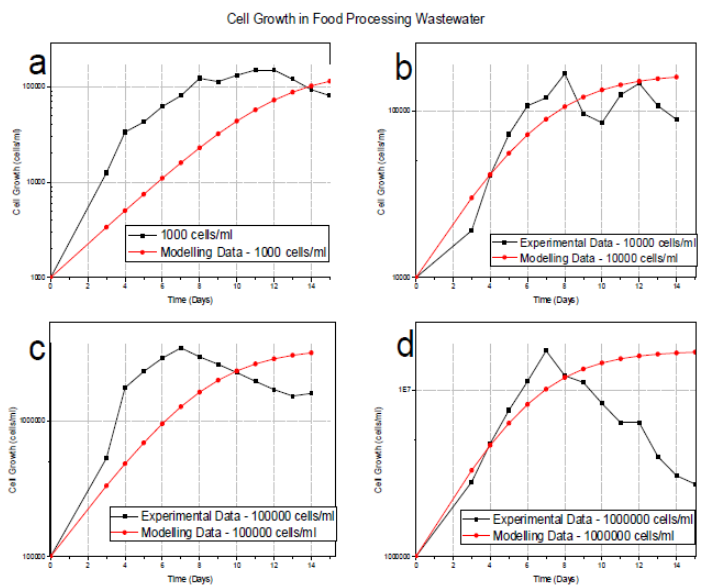

Fig. 3. a) Cell growth of Scenedesmus sp. for $1 \times 10^{3}$ cells $/ \mathrm{ml}$ concentration; b) Cell growth of Scenedesmus sp. for $1 \times 10^{4}$ cells $/ \mathrm{ml}$ concentrations; c) Cell growth of Scenedesmus sp. for $1 \times 10^{5}$ cells $/ \mathrm{ml}$ concentration; d) Cell growth of Scenedesmus sp. for $1 \times 10^{6}$ cells $/ \mathrm{ml}$

Table 3. Comparison of growth parameters between experimental data and mathematical modelling for Scenedesmus $s p$. in different initial of concentrations.

\begin{tabular}{|c|c|c|c|c|c|}
\hline \multirow[b]{2}{*}{$\begin{array}{l}\text { Concentration } \\
\text { (cells } / \mathrm{ml})\end{array}$} & \multicolumn{5}{|c|}{ Experimental Data } \\
\hline & $\begin{array}{c}\text { Max Specific } \\
\text { Growth Rates } \\
\text { max/day }\end{array}$ & $\begin{array}{l}\text { Division } \\
\text { per day } \\
\text { (Dd) }\end{array}$ & $\begin{array}{c}\text { Doubling } \\
\text { Time, td } \\
\text { (day) }\end{array}$ & $\begin{array}{c}\text { Biomass } \\
\text { productivity } \\
\text { (cells/ml/day) } \\
\mathbf{1 0}^{4}\end{array}$ & $\mathbf{R}^{2}$ \\
\hline $1 \times 10^{3}$ & $0.4108 \pm 0.0425$ & 0.5927 & 1.687 & 14.9 & 0.9393 \\
\hline $1 \times 10^{4}$ & $0.4125 \pm 0.0583$ & 0.5951 & 1.680 & 16.8 & 0.9321 \\
\hline $1 \times 10^{5}$ & $0.4250 \pm 0.0308$ & 0.6131 & 1.631 & 348.0 & 0.8187 \\
\hline $1 \times 10^{6}$ & $0.4483 \pm 0.0244$ & 0.6468 & 1.546 & 1720.0 & 0.9967 \\
\hline $1 \times 10^{7}$ & 0 & 0 & 0 & 0 & 0 \\
\hline
\end{tabular}

* Experiments conducted in triplicate manner $(n=3)$

The specific growth rates of biomass increases with microalgae concentration until they reached a maximum value that associate with optimal concentrations, concentration $1 \times 10^{6}$ cells $/ \mathrm{ml}$ shows the highest specific growth of biomass increment followed by $1 \times 10^{5}$ cells $/ \mathrm{ml}, 1 \times 10^{4}$ cells $/ \mathrm{ml}$ and $1 \times 10^{3}$ cells $/ \mathrm{ml}$ with specific growth rates of 0.4483 day $^{-1}$, 0.4250 day $^{-1}, 0.4125$ day $^{-1}$ and 0.4108 day $^{-1}$ respectively. Beyond these concentrations, it can be considered as saturated phase where the growth rapidly decreased or no growth occurred [33]. As per $1 \times 10^{6}$ cells $/ \mathrm{ml}$, the exponential curve starts from day 3rd until day 7 th, similarly to $1 \times 10^{5}$ cells $/ \mathrm{ml}$ while $1 \times 10^{4}$ cells $/ \mathrm{ml}$ and $1 \times 10^{3}$ cells $/ \mathrm{ml}$ starts their exponential curve at day 3rd until day 8th correspondingly. In identifying specific growth rates, can be directly obtained by applying Equation (1). Biomass productivity on the other hand shows some significant increments for all concentrations, particularly for $1 \times 10^{6}$ cells $/ \mathrm{ml}$ with maximum biomass productivity and specific growth rates of 1720 cells $/ \mathrm{ml} /$ day and 0.4483 day $^{-1}$. This results are slightly higher than the results obtained by [34] studies with specific growth rates of 0.103 day $^{-1}$ when they cultivate Scenedesmus $s p$. in municipal wastewater and biomass productivity up to $50.75 \mathrm{mg} / \mathrm{L} /$ day (dried weight) [35]. The specific growth rate obtained in this study is slightly higher than study done by [36] with maximum specific growth rate of 0.17 day $^{-1}$, and biomass production of 253.45 
$\mathrm{mg} / \mathrm{l}$ in terms of dry weight by using BG-11 medium media during cultivation of Scenedesmus SDEC-8. Moreover, chrollella SDEC 4 on the other hand obtained 0.18 day $^{-1}$ of maximum specific growth rate with $157.30 \mathrm{mg} / \mathrm{l}$ in terms dry weight of biomass production. Different species will give different growth rates due to its algometric relationship between growth and cell size as well as metabolic process, resulting smaller size of species tends to grew faster than the bigger size [33], same goes with different media or medium used.

\section{Conclusion}

The series of experiments conducted here are aimed to access and verified the best concentration of microalgae scenedesmus sp. cultivating in Industrial Meat Food Processing Wastewater. The results shows concentration of $1 \times 10^{6}$ cells $/ \mathrm{ml}$ of microalgae scenedesmus $s p$. gives the highest specific growth rates biomass of 0.4488 day- 1 . Thus, from these findings, the most adequate population that suitable for sustaining the microalgae scenedesmus sp. growth in Industrial Meat Food Processing Wastewater is verified. This study is another small chapter on accessing the effectiveness of cultivating microalgae Scenedesmus $s p$. in industrial meat food processing wastewater for wastewater purification and biomass productivity, as the culturing microalgae in industrial meat food processing wastewater are highly dependable on wastewater nutrients availability as well as initial cell concentrations. Therefore, more research on microalgae Scenedesmus sp. would be essentials for phycoremediation and potentially biomass.

This research was funded under the FRGS (Vote 1435) and eScience Fund project no: 02-01-13SF0135. The authors thank to any parties that involved in this project especially Universiti Tun Hussein Onn Malaysia for providing the equipment and research facilities to carry out this project.

\section{References}

[1] Y. Wu, H. Hu, Y. Yu, T. Zhang and S. Zhu, Microalgal species for sustainable biomass lipid production using wastewater as resource: A review, Renewable and Sustainable Energy, 336, 75-688, (2014)

[2] A. Richmond, Handbook of microalgal culture: biotechnology and applied phycology. Blackwell Science Ltd; (2004)

[3] J. P. Maity, J. Bundschuh, C.-Y. Chen, and P. Bhattacharya., Microalgae for third generation biofuel production, mitigation of greenhouse gas emissions and wastewater treatment: Present and future perspectives - A mini review, Energy, 78, 104-113, (2014)

[4] D. Hanelt, K. Bischof and K. Dunton, Life strategy, eco-physiology and ecology of seaweeds in polar waters, Reviews in Environmental Science and Biotechnology 2007, 6(1), 95-126, (2007)

[5] A. Al-Darmaki, L. Govindrajan, S. Talebi, S. Al-Rajhi, T. Al-Barwani, Z. Al-Bulashi, Cultivation and characterization of microalgae for wastewater treatment. Proceedings of the world congress on Eng. 1,(2012) 
[6] D. S. Shekhawat, A. Bhatnagar, M. Bhatnagar, and J. Panwar, Potential of Treated Dairy Waste Water for the Cultivation of Algae and Waste Water Treatment by Algae, J. Environ. Res. Technol., 2, 101-104, (2012)

[7] A. Worku and O. Sahu, Reduction of Heavy Metal and Hardness from Ground Water by Algae, J. Appl. Environ. Microbiol., 2(3), 86-89 (2014)

[8] X.E. Yang, X. Wu, H.L. Hao, and Z.L. He, Mechanisms and assessment of water eutrophication. J. Zhejiang Univ. Sci. B. 9(3), 197-209, (2009)

[9] Onet C., Characteristics of the Untreated Wastewater Produced By Food Industry Vol Xv, 709 - 714, University of Oradea- Faculty of Environmental Protection, (2010)

[10]E. Sroka, K. Wladysław, and B. Jolanta, Biological Treatment of Meat Industry Wastewater, Desalination 162, 85-91, (2004)

[11]C. F. Bustillo-Lecompte and M. Mehrvar, Slaughterhouse wastewater characteristics, treatment, and management in the meat processing industry: A review on trends and advances, J. of Environmental Management, 161, 287-302, (2015)

[12] W. Qasim and A. V. Mane, Characterization and treatment of selected food industrial effluents by coagulation and adsorption techniques, Water Resources and Industry, 4, $1-12,(2013)$

[13]J. Liu, Z. Sun, and H. Gerken, Recent Advances in Microalgal Biotechnology. Potential Application of Microalgae Wastewater Treatment. OMICS Group eBooks, (2014)

[14] V. H. Smith, G. D. Tilman, and J. C. Nekola, Eutrophication : impacts of excess nutrient inputs on freshwater, marine, and terrestrial ecosystems, Env. Pollution, 100, 179-196, (1999)

[15]Z-F, Su, X. Li, H-Y, Hu, Y-H, Wu, T, Noguchi, Culture of Scenedesmus sp LX1 in the modified effluent of a wastewater treatment plant of an electric factory by photomembrane bioreactor. Bioresource Technology 1; 102, 7627-32. (2011)

[16]T. Kallquist, A. Svenson, Assessment of ammonia toxicity in tests with the microalga, Nephroselmispyriformis, Chlorophyta. Water Res., 37, 477-84, (2003)

[17]X. Yuan, A. Kumar, AK. Sahu, and Sj. Ergas. Impact of ammonia concentration on Spirulina platensis growth in an airlift photobioreactor, Bioresour. Technol., 102(3), 234-9, (2011)

[18] Gani, P. S. Sunar, N. M. M. A. Peralta, H. A. B. L. Latiff, and A. A. A. B. R. Razak, Influence of Initial Cell Concentrations on the Growth Rate And Biomass Productivity of Microalgae In Domestic Wastewater, 14(2), 399-409, (2016)

[19]N.A.A. Latiffi, S. Radin, N.M. Apandi and H. Mohd, Application of Phycoremediation using Microalgae Scenedesmus sp. as Wastewater Treatment in Removal of Heavy Metals from Food Stall Wastewater, J. of Applied Mechanics and Materials, (773 774), 1168 -1172, (2014)

[20]Nichols Hw and Bold Hc., Hand Book of Physiological Methods, Growth mediaFresh Water, Cambridge University, London, U.K., 7-24, (1965)

[21]F. H. Stephenson, Calculations for Molecular Biology and Biotechnology, Elsevier's Science and Technology, Oxford, U.K., (2010)

[22]Mi. L. Shuler, Bioprocess Engineering-Basic Concepts (2nd Edition), Prentice Hall PTR, New Jersey, U.S.A., (2002) 
[23] APHA (AMERICAN PUBLIC HEALTH ASSOCIATION), Standard Methods for Examination of Water and Wastewater (21stedn.), American Public Health Association, Washington DC, U.S.A., (2012)

[24]R. A. Andersen, Algae culturing technique, Elsevier's Science and Technology, Oxford, U.K., (2005).

[25]E. A. Echiegu and J. T. Liberty, Effluents Characteristics of Some Selected Food Processing Industries in Enugu and Anambra States of Nigeria, J. of Environment and Eart Science, 3(9), 46-54, (2013)

[26]Environmental Quality Act 1974, Department of Environmental Malaysia: A Guide For Investor, Putrajaya, Malaysia, (2010)

[27]L. Creswell, Phytoplankton Culture for Aquaculture Feed, Florida, US, (2010), $\begin{array}{lllll}\text { Retrieved on } & \text { August } & 23 . & & \end{array}$ http://www2.ca.uky.edu/wkrec/PhytoplanktonAlgaeCulture.pdf

[28]P. Gani, N. M. Sunar, H. Matias-peralta, A. Aziz and A. Latiff, Application Of Phycoremediation Technology In Thetreatment Of Food Processing Wastewater By Freshwater Microalgae Botryococcus Sp., Applied Ecology and Environmental Research, 11(11), 7288-7292 (2016)

[29]T.-Y. Zhang, Y-H. Wu, S-F. Zhu, F-M. Li, H-Y. Ho, Isolation and heterotrophic cultivation of mixotrophic microalgae strains for domestic wastewater treatment and lipid production under dark condition, Bioresource Technology 149, 586-9 (2013)

[30]Ş.S. Can, V. Demir, S.A. Korkmaz, E. Can, Treatment of domestic wastewater with Botryococcus braunii (Cholorophyceae), J. of Food, Agriculture and Environment, 11(4\&3) 3-5 (2013)

[31]M.-K. Ji, R-A.I. Abou-Shanab, S-H. Kim, E-S. Salama, S-H. Lee, A.N. Kabra, Y-S. Lee, S. Hong, B-H. Jeon, Cultivation of microalgae species in tertiary municipal wastewater supplemented with $\mathrm{CO} 2$ for nutrient removal and biomass production, Ecological Engineering 58, 142-148, (2013)

[32]Z. Arbib, J. Ruiz, P. Álvarez-Díaz, C. Garrido-Pérez, and J. a. Perales, Capability of different microalgae species for phytoremediation processes: Wastewater tertiary treatment, $\mathrm{CO}_{2}$ bio-fixation and low cost biofuels production, Water Research, 49, $465-474$ (2014)

[33]R. Bouterfas, M. Belkoura, P. M. Abdellah, S, B. P., D. Narbonne, and T. Cedex, The effects of irradiance and photoperiod on the growth rate of three freshwater green algae isolated from a eutrophic lake Source of the organisms isolated from the eutrophic Takerkoust barrage' s, 25(3), 647-656, (2006)

[34]M. S. De Alva, V. M. Luna-pabello, E. Cadena, and E. Ortíz, Green microalga Scenedesmus acutus grown on municipal wastewater to couple nutrient removal with lipid accumulation for biodiesel production, Bio resource Technology146, 744-748, (2006)

[35]D.Y. Shin, H.U. Cho, J.C. Utomo, Y.-N. Choi, X. Xu and J.M. Park, Biodiesel production from Scenedesmus bijuga grown in anaerobically digested food wastewater effluent, Bio resource technology 184, 215-21, (2015)

[36] M. Song, H. Pei, W. Hu, S. Zhang, G. Ma, L. Han, and Y. Ji, Identification and characterization of a freshwater microalga Scenedesmus SDEC-8 for nutrient removal and biodiesel production, Bio resource Technology, 162, 129-135, (2014) 